\title{
Instructor immediacy strategies to facilitate group work in online graduate study
}

\author{
Sherri Melrose and Kim Bergeron \\ Athabasca University
}

\begin{abstract}
An increasing number of online graduate study programs require students to participate in collaborative work projects. And yet, educational research examining instructional strategies that facilitate learning in small groups online is limited. This article describes findings from a qualitative research project that investigated instructor immediacy at different stages of group development. The research was framed from a constructivist theoretical perspective and a descriptive research design. Participants were health care practitioners from two WebCT online graduate study programs. Data sources included four focus groups and twenty individual audio recorded transcribed interviews. The data was collected in person over a three year period, analysed for themes by two researchers, and confirmed with participants through ongoing member checking. Instructional immediacy strategies that students believed facilitated meaningful learning in small groups are presented in the three overarching stages of first, beginning/ engagement; second, middle/ encouragement; and third, ending/ closure. Findings suggested that, in the beginning/ engagement stage, learners valued knowing their instructors were available "if you need me" and that it was "safe" to contact them. In the middle/ encouragement stage, they appreciated personal help with networking and managing conflict, particularly in relation to participation and marking and they valued private feedback. And, in the ending/ closing stage, they needed opportunities to debrief and reflect.
\end{abstract}

\section{Introduction}

Instructors who demonstrate immediacy are well-received by students in a variety of different learning events. Health care professionals undertaking graduate study in online environments, particularly when they are required to work in small groups, value feeling personally connected and close to their teachers. However, the processes involved in linking the construct of immediacy to facilitation strategies for small group work online are not well understood. Groups can be expected to progress through predictable developmental stages, and it is important for 
instructors to implement relevant and specific strategies that learners themselves value in a personal way during each of these stages. Three key areas of theoretical understanding provide background for this study - the construct of instructor immediacy, predictions of learning group development, and the individual needs of group members.

\section{Literature review}

\section{The construct of instructor immediacy}

The construct of immediacy was originally presented by social psychologist Albert Mehrabian in the 1960s, and was defined as an affective expression of emotional attachment, feelings of liking and being close to another person (Mehrabian, 1967; 1971; Weiner \& Mehrabian, 1968). In traditional higher education classrooms, instructional immediacy was further defined as a non verbal manifestation of high affect and is demonstrated through maintaining eye contact, leaning closer, touching, smiling, maintaining a relaxed body posture and attending to voice inflection (Andersen, 1979). Verbal components of the construct include using personal examples, engaging in humour, asking questions, initiating conversations with students, addressing students by name, praising student work, and encouraging student expression of opinions (Gorham,1988). Links between teacher immediacy, student motivation and affective learning have been well documented (Christophel, 1990; Christophel \& Gorham, 1995).

In online classroom environments, where non verbal cues are absent, the construct is not as easy to articulate. However, associations between instructor immediacy behaviours and student learning and satisfaction are significant (Arbaugh, 2001). The experience of liking and feeling close to instructors can lead to positive effects in online classrooms (Hess \& Smythe, 2001). Correlations between immediacy and affective learning exist (Baker, 2004; Russo \& Benson, 2005). And, immediacy behaviors are believed to enhance instructional effectiveness (Hutchins, 2003; Woods \& Baker, 2004).

\section{Predictions of learning group development}

Predictions of learning group development suggest that small groups will typically progress through expected stages. Tuckman's $(1965,1977)$ seminal work identified that small groups will progress through the five stages of forming (characterised by anxiety and uncertainty about belonging); storming (characterised by competition, individuality and conflict); norming (characterised by attempts to resolve earlier conflicts, clear expectations of behaviors and roles); performing (characterised by cooperation and productive work); and adjourning (characterised by termination and 
disengagement from the group). Later, Johnson and Johnson (1997, 2000) identified that students in small groups will progress through the seven stages of defining and structuring procedures and becoming oriented, conforming to procedures and getting acquainted, recognising mutuality and building trust, rebelling and differentiating, committing to and taking ownership of the goals and other members, functioning maturely and productively and, finally, terminating.

In online classroom environments, groups are also are expected to progress through similar stages. And yet, Palloff and Pratt (1999) noted that aspects of communication affecting group interactions may be significantly different. Salmon (2004) identified that students who are separated from one another by time and distance will progress through the five stages of access and motivation (characterised by welcoming and encouraging); online socialisation (characterised by familiarising and providing bridges between cultural, social and learning environments); information exchange (characterised by facilitating tasks and supporting use of learning materials); knowledge construction (characterised by facilitating process); and development (characterised by supporting and responding). In addition, Salmon (2004) suggested that computer networking requires learners to understand technological aspects of online interpersonal communication and networking. Describing an 'interactivity bar,' she asserted that the intensity of interaction will be different at each stage of development. Examining pre-masters health professionals' transitional process while engaged in online learning, Giddings, Campbell and Maclaren (2006) identified four stages where learners progress through 'virtual paralysis,' 'engagement,' 'getting into it' and ultimately 'surprised enjoyment.'

\section{Individual needs of group members}

Individual needs of group members create an important dynamic within small group projects. Maslow (1982) asserted that individuals all have a hierarchy of needs where survival needs (physiological needs for air, water and food; and safety needs for security and protection) must be fulfilled before they can meet the psychological needs for esteem, belonging and self actualisation. When individuals become members of groups, Beebe and Masterton (2006) explained that they need groups to satisfy different needs. While some may have a high need for safety within a group, others may have a high need for esteem and respect from the group. And, when aspects of individuals' personal survival and psychological needs are not being met, limited participation in a group can be expected.

When individuals form and interact in groups, Schutz's (1958) classic theory of interpersonal behaviour postulated that they also all have needs for inclusion (feeling recognised and included and reaching out to make 
others feel included), control (feeling in control, contesting issues, vying for leadership and resolving conflicts) and affection (giving and receiving emotional support). Facilitating balance between individuals' needs as group members and the need for a group to progress is not straightforward. Instructor immediacy, where students like their teachers and feel emotionally close to them, can begin to offer guidance.

Existing direction to help instructors balance students' needs both as individuals and as members of small groups are limited. Resources such as Barker, Wahlers and Watson (2001), Clark (2003) and Westberg and Jason (1996) offer general help for facilitating group communication processes. Bates and Poole (2003) and Collison, Elbaum, Haavind and Tinker (2000) offer explicit help for facilitating online groups. Further, the specific processes involved in creating an effective teaching presence in online classrooms have also been examined (Anderson, 2004; Anderson, Rourke, Archer et al., 2001; Garrison, Anderson \& Archer, 2000; Stacey \& Rice, 2002). However, little guidance is available on specific ways instructors can continue to support students as individuals during the times they are members of small groups. As McLoughlin (2002) asserted: "Placing students in groups and assuming that this will bring about collaboration is mistaken, as negative group interaction may hinder rather than promote effective team behaviours" (p.252).

One resource, a workbook developed by Carr, Herman, Zarotney-Keldsen et al. (2005a) offers activity templates that participants in small group learning teams online can complete at different stages of their development. An instructor resource manual accompanying the student workbook (Carr, Herman, Zarotney-Keldsen et al., 2005b) offers suggestions on integrating team learning in course syllabi; creating teams; developing team contracts to establish ground rules, expectations for performance and criteria for performance feedback and evaluation of each team member; managing meetings and conflict; peer feedback; after action review and evaluation and closing. However, Carr Herman, ZarotneyKeldsen et al's (2005a; 2005b) suggestions are grounded in the belief that students are accountable for their performance and for the requirements of the course when they work in small group learning teams. Within this approach, individual learning needs of group members are once again not addressed.

\section{The research approach}

The goal of the research was to listen to the voices of students who successfully completed their graduate studies online, in order to understand the kinds of instructional strategies that were meaningful to them. The program of research addressed both the topic of student help 
seeking and the topic of instructor immediacy. With the topic of help seeking, the initial phase of the work explored online graduate students' help seeking behaviours (Melrose, Shapiro \& LaVallie, 2005). Next, in response to students' belief that their primary source of help was other students in their class, strategies to facilitate student interaction were described (Melrose, 2006).

With the topic of instructor immediacy, when it became apparent that students' valued teaching strategies that demonstrated immediacy and found them helpful, the next phase of the work examined the concept of instructor immediacy in depth (Melrose \& Bergeron, 2006). Later, within the process of investigating learners' experiences with helpful and immediate instructional behaviours and their interactions with one another, issues related to working in groups emerged. Bergeron and Melrose (2006) identified students' perceptions of issues that they faced during group work and the instructional strategies that helped. The present article elaborates on the next phase of the research, where specific facilitation strategies are described to demonstrate instructor immediacy during different stages of group development.

The purpose of this qualitative research was to explore health care students' ideas about instructor immediacy at different stages of their small group work, within a masters program offered exclusively through an asynchronous, text based, WebCT online environment. Student participants included nurses, social workers, dieticians, occupational therapists and physicians. They were predominantly female and lived in countries all around the world. This project was framed from a constructivist theoretical perspective (Appleton \& King, 2002; Kelly, 1955; Piaget, 1954; Vygotsky, 1978) in that knowledge is believed to be constructed through an individual's interactions with social processes and contexts. The research design was descriptive and the findings a case study representation of two health care graduate programs offered in English at Athabasca University, an open Canadian Distance Education University. The work was guided by the questions: what issues do online graduate learners face during the beginning, middle and end stages of their small group work; and what instructional behaviours are helpful in addressing these issues.

The methods included collecting data from four focus groups and twenty individual audio recorded transcribed interviews. Each focus group consisted of seven or eight participants. The data was collected over a three year period, from 2003 through to 2005, to include personal contact with the 31 participants when they attended Convocation ceremonies at the Athabasca University campus in Athabasca, Alberta, Canada. 
Content from these data sources were analysed first independently and then collaboratively by the researchers. The transcripts were read numerous times and on different occasions to glean a thorough understanding of the phenomena and allow the researchers to become immersed in the data. A systematic process of content analysis was developed (Denzin \& Lincoln, 1994; Lincoln \& Guba, 1985; Loiselle, Profetto-McGrath, Polit et al., 2007). Specifically, as the transcripts were read, color coded fonts and highlighting were used to extrapolate descriptive phrases. Throughout the process of organising these descriptive phrases in relation to similarities and patterns, Microsoft Word files were created to index the categories of information which repeated in a patterned fashion and constituted themes. In order to reflect on the data and re-examine the files for consistency, weekly email and telephone appointments were established between the researchers, who were separated by time and distance.

Trustworthiness and credibility was established through ongoing interaction and member checking with participants to ensure authenticity. Information was clarified with participants after the interviews through email communication. To ensure anonymity, pseudonyms were used when participants' comments are reported verbatim. Full ethical approval was granted from the Athabasca University Ethics Committee for each phase of the work and all participants gave informed consent.

As an organising schema, the themes are presented by integrating the Tuckman (1965), Johnson and Johnson (1997, 2000) and Salmon (2004) predictive models of learning group development into three stages: beginning, middle and end. First, learners can be expected to progress through a beginning stage where engagement with content and process issues occurs; second, through a middle stage where encouragement towards task completion occurs; and third, through an ending stage where closure occurs. At each stage, participants in this project valued different instructor immediacy behaviours.

\section{Findings}

\section{The beginning/ engagement stage}

\section{Availability}

When participants in the present research discussed their initial recollections about beginning to work in small groups, they consistently expressed a need to know that their instructor would remain attentive to their needs as individuals. Instructors who communicated: "I'm here if you need me" were perceived as available to them, immediate and present. 
Students identified that their instructors' first introductory postings communicated whether or not they were genuinely available. As Carrie stated: "I found that first introduction really gave you a sense of how closed or open the instructor was". Paul commented:

Instructors I felt comfortable with set the stage about who they were right off the bat in their introductions. That was very important to me. But, there were other instructors who were quite invisible. You didn't see them. They said that right in the beginning. That that was their style, to stand back unless they were asked questions. That behaviour right away I felt like, well they are not that interested in us and I was less likely to approach them.

Visual cues such as including instructor names on each small group roster and posting online office hours for chat room discussions were further demonstrations of instructor availability. And, directing students to contain their communication within the WebCT class environment instead of engaging in phone or face to face conversations suggested that instructors would be observing group communication.

\title{
Safety
}

From the students' perspective, where designating final mark assignments were controlled by instructors, feeling that it was "safe" to reach out for individual help when they needed it was critical. As Donna explained:

\begin{abstract}
It's the teachers who are marking, and that's how we're going to get through this course. So, their perceptions and what they want is very important. I didn't mind working in groups, but there has to be a mechanism where you feel safe to able to comment about the groups.
\end{abstract}

Discussing how she did not feel that it was acceptable to contact one instructor when an issue emerged during group work, Megan stated: "I thought about going to the professor and then decided not to. I thought it would be obvious enough." Derek added:

Instructors see the postings. You know big brother is watching, but not intervening at all, so you're not really sure if it's safe [to make contact].

\section{The middle/ encouragement stage}

\section{Networking}

Students appreciated instructional help to join appropriate groups and to network. While some students who had completed a number of classes within the program expressed comfort in self selecting group membership, Kelly felt "letting us sit out there and go 'anybody want to work with me'?" was frustrating. Discussing the difficulties of requiring individuals from different geographical areas to create their own online groups, Vidushi explained that 
...if you don't know anybody, and haven't seen the names before, you really don't know how to approach [classmates], that was tough.

Carol advised: "Maybe the instructor could pull people together in the groups. Newer students don't have the background, help us share some little personal thing and then we can build on it to get to know each other." Instructor initiated networking opportunities such as inviting students to post introductions and pictures were viewed as helpful. Sean described how important it was for

$$
\begin{aligned}
& \text {...instructors to spend some time at the beginning [of the project] } \\
& \text { encouraging us to introduce ourselves to one another and provide some } \\
& \text { biographical information. That really helped make others in the group more } \\
& \text { than just a name. It really encouraged you to start looking at people as } \\
& \text { people and to share what we were doing both in careers and personal life. } \\
& \text { That built networking. }
\end{aligned}
$$

\section{Conflict}

Conflict within small group work can be expected and, when managed well, can strengthen learning. However, conflict can also cause undue anxiety and frustration. It is within the experience of conflict where instructor immediacy may offer significant insight. Articulating a clear understanding of instructor and student expectations, particularly in relation to participation and marking is critical. As professional health care providers, many of the online graduate students participating in the present study were experienced group facilitators themselves. Familiar with the importance of establishing rules or guidelines and roles and responsibilities within groups, they were nonetheless appreciative of instructor direction.

\section{Participation}

\section{Discussing participation, Jin expressed:}

I think part of the challenge with groups, and it needs to be clear up front, you develop your group norms, your group expectations, but [what about] the instructors? There's always that sense that they can see maybe people aren't participating, that the group is asking 'where's your work', 'what do you think about that.' And the instructors are not sort of jumping in.

Cara added "You HOPE they're looking!" Knowing what they could expect in terms of involvement from their instructors helped students to in turn establish expectations with one another in their groups.

Early instructor guidance directing groups to determine consequences for limited participation was useful. Students described situations where groups agreed to "fire" non-participants and other situations where missed meetings and commitments were tolerated. In these experiences, whether 
they remained included in a group or experienced the rejection of being excluded, students valued feeling close to their teachers. Clearly, expressing immediacy within the process of supporting individuals towards withdrawing from courses can be expected to strengthen the experience.

By count, students emphasised problems with group participation the greatest number of times during the research discussions. Descriptions included "others not doing their share," "carrying others," "doing work for them" and "others getting marks without doing the work." When asked about instructor immediacy strategies that were perceived as helpful responses to participation issues, Lisa described an experience in one course where her instructor "designated a group leader." She continued:

We didn't always do that, the professor asked us that time. [There were some problems with participation.] It allowed the professor to deal privately with one person if something was happening. She said, 'there's seems to be a bit of an issue, do you need my help or are you going to deal with it [in your group] first?' That's what happened in the group that we had a huge problem with.

Marking

With regard to marking, reflection on incidents where instructor expectations were not clear stood out for students. Wiping tears from her eyes, Mary disclosed:

I never fought for something and there's one course that I fought the teacher because I was upset [about] the way she did the marking. How she explained it was so convoluted to start with, and then the way she assigned it! In essence, she said that we all marked ourselves within our own group at $60 \%$. I knew we hadn't because we discussed it, we said we assign, we would each do our own mark, but we all felt that we put in equally, so we would mark above a certain number. Well I called, I was so upset, and I have never in all these years fought a teacher for anything, I fought this one. And it was very disheartening to say the least.

In further discussions with Mary, it was clear that although the incident had occurred well over a year previously, she continued to feel troubled by the memory and still did not understand her instructor's marking expectations in that assignment.

Private feedback

In addition to providing students with clear directions about the level of instructor involvement that they could expect and how their assignments would be marked, students welcomed private emails from their instructors once their small group project work was underway. During the focus group discussions, participants frequently mentioned how private emails 
"opened the door" to share their individual needs. Whether it was difficulties at home, at work or even "with technology," private emails from their instructors invited students to explore issues such as their participation.

Individual mid term evaluations, as well as requiring groups to submit formative evaluations of their progress was seen as helpful. Privately asking students about how they felt they were progressing and providing some feedback on their contribution to their small group was valuable, "Some indication that you're on the right path." In Beth's words: "Ask how [a student] is doing. How are you doing - and continue to explore that. It's an easy question."

Students commented on how private instructor feedback about participation could be very "powerful," particularly when participation was limited but there was still time remaining in the course. Discussing student-to-student feedback in response to limited participation, Jill stated:
You don't know what else is happening with that person's life. You don't want to drive them out [of the course] and add extra stressors to them when they already can't cope. But I have actually been in almost - you know, not every course, but a lot of courses, where a good $50 \%$ of the group isn't functional.

Urmy also acknowledged challenges in offering negative feedback to fellow group members.

It's hard to say 'you're not really pulling your weight here, can we help you out in another way?' You wonder, are we too assertive? It's a very personal question. That's a tough behaviour to learn online.

On the other hand, when students were demonstrating strong participation, private instructor affirmations were very encouraging. When Karen shared that she worried she wasn't contributing, her instructor sent an email stating "I don't know why you're saying this because what you bring is very valuable." Instructor responses such as "yeah, that's exactly the way I'd like to see it" were heartening.

Although participants in the present study did not agree on whether marks for small group work should be the same for all members, the issue was mentioned frequently during the research discussions. Bruce questioned:

What do you do when your group members just aren't functioning? And it happened a fair bit. I was in some good groups and I was in some really crummy groups. But everyone gets the same mark, and if you were to say anything you feel like you're going to be - you don't know - am I going to be docked? 
However, once again, instructor responses that demonstrated immediacy were perceived as positive elements within the experience of group, especially during times of conflict. Anna summarised:

The instructor(s) would gently bring things back to probably what the learning objectives of the course and that kind of thing were. They set some of those limitations ... Tell you to focus or re-do, [that] was so helpful.

\section{The ending/closure stage}

\section{Debriefing}

Inviting students to formally debrief their experiences by encouraging them to share with others what they learned was viewed as helpful during this stage. Commenting on how students' posted their final products for colleagues to review and critique, Mae-Ling stated: "Sharing resources like that was big and helpful and certainly lent to the feel that this was a good thing". "Celebrations" and "virtual wine and cheese parties when it was over" were "fun."

\section{Reflection}

In addition to discussing content that groups had worked on, opportunities to debrief group process were needed. In the present research, as participants reflected on their experiences, few comments about closure in individual courses were expressed. Angie enjoyed how

...one professor particularly wrote a summary of all our feelings and then skilfully put them together and she added some of her perspectives - which I really thought was just amazing. It made it just much more personable for us as a group.

Failure to achieve closure with a small group experience can leave learners feeling unsettled long after the learning event has ended. As Mary's earlier comments reflect, even a year after her class, a lack of understanding about how her group had been marked left her tearful and feeling she had to "fight" with her teacher.

It is interesting to note that, throughout the research discussions, participants consistently commented on how much they valued the process of talking about their learning experiences. There was general agreement that the present project served as an important opportunity for students to reflect and debrief at the end of their program.

\section{Discussion}

The findings presented above illustrate stage specific instructor immediacy strategies that health care learners believed were helpful during their small 
group work. Listening attentively as students who successfully completed graduate studies online shared their memories offered important insights.

In the beginning stage of small group work, where engagement with both tasks and one another was required, students' valued messages from their instructors that communicated a genuine willingness to remain available and present. This finding is consistent with Giddings, Campbell and Maclaren's (2006) work emphasising the importance of early personal communication between online health care learners and their teachers. On an affective level, when assessing the safety of an online learning environment, students felt that it was instructors' first introductory messages that determined whether they were immediate or not. And, students identified that they consistently remained aware of instructors' ultimate control of marking.

In the middle stage of small group work, where encouragement to work through and complete projects was required, students' appreciated personal help with networking and managing conflict, specifically in the areas of participation and marking. Facilitation strategies, such as compiling picture and biographical summaries of group members were helpful in presenting students personally and professionally to one another. Instructors' private feedback through emails, mid-term evaluations and participation assessments demonstrated immediacy and an ongoing awareness of their students' individual learning needs. Explicit rubrics for marking both group processes and products reduced uncertainty.

Instructors who were perceived as immediate were those who had contingency plans in place for constructive conflict management. Examples that stood out for participants in the present research included asking project groups whether they wished to resolve the conflict themselves or with instructor help and designating one member of the group as a spokesperson. Adaptations of Carr, Herman, Zarotney et al's (2005a) activity templates for team contracts, meeting management, peer feedback and after action reflection also offer useful suggestions. Areas of online group conflict identified by students in the present research are similar to the non-participation issues described by Anderson and Simpson (2004), the time consuming nature of the group commitment described by Gabriel (2004) and the anxious and defensive group dynamics described by Creese (2003).

In the ending stage of small group work, where closing with the learning experience was required, students needed opportunities to debrief and reflect. When these opportunities were absent or incomplete, negative memories persisted. And, the negative memories were linked more to 
feeling limited immediacy with instructors than with anger towards fellow students or with earning low marks. On the other hand, ending project group work with planned time for reflective activities, instructors' written summaries of group work and measurement of individual as well as group progress stimulated positive memories of meaningful learning. As Eggleston and Smith (2002) and Yonge, Lee and Luhanga (2006) emphasised, programs that portray themselves as learner oriented need to be mindful of parting-ways activities to close and not just end their courses.

\section{Conclusion}

This article presented findings from a descriptive research study that explored online graduate students' perceptions of instructor immediacy strategies which were helpful at different stages of small group work. In contrast to other studies, the present investigation extends our understanding of online group facilitation approaches to include the possibility that students' need for instructor immediacy may be greatest during the times they are required to work in small groups.

Traditionally, educators have expected students who are members of project groups to assume responsibility for their dynamics when they work together on a learning task. However, viewing the experience of participating in online groups through the eyes of students, we see that instructor immediacy is a critical element in acting on that responsibility. Liking and feeling close to their teachers helped these graduate learners feel safe, encouraged them to risk participating in group projects and allowed them to achieve closure. The research process itself offered a valuable personal opportunity for online learners to discuss their experiences. The work emphasises an important need to continue researching the kinds of instructor immediacy strategies that can be helpful in facilitating online group work.

\section{Acknowledgements}

The authors wish to acknowledge funding from the Mission Critical Research Fund, Athabasca University

\section{References}

Andersen, J.F. (1979). Teacher immediacy as a predictor of teaching effectiveness. Communication Yearbook, 3, 543-559.

Anderson, B. \& Simpson, M. (2004). Group and class contexts for learning and support online: Learning and affective support online in small group and class 
context. International Review of Research in Open and Distance Learning (IRRODL), 5(3). http: / / www.irrodl.org/index.php/irrodl/article/viewArticle/208/291 [viewed 24 Feb 2007]

Anderson, T., Rourke, L., Archer, W. \& Garrison, R. (2001). Assessing teaching presence in computer conferencing transcripts. Journal of Asynchronous Learning Networks, 5(2). [viewed 24 Feb 2007]

http:/ / www.aln.org/publications/jaln/v5n2/v5n2_anderson.asp

Anderson, T. (2004). Teaching in an online learning context. In T. Anderson \& F. Elloumi (Eds.), Theory and practice of online learning (pp. 273-294). Athabasca, AB: Athabasca University Printing. http:/ / cde.athabascau.ca/online_book/ [viewed $24 \mathrm{Feb}$ 2007].

Appleton, J., King, L., 2002. Journeying from the philosophical contemplation of constructivism to the methodological pragmatics of health services research. Journal of Advanced Nursing 40(6), 641-648.

Arbaugh, J. B. (2001). How instructor immediacy behaviors affect student satisfaction and learning in Web-based courses. Business Communication Quarterly, 64(4), 42-54.

Baker, J. D. (2004). An investigation of relationships among instructor immediacy and affective and cognitive learning in the online classroom. Internet and Higher Education, 7, 1-13.

Barker, L., Wahlers, K. \& Watson, K. (2001). Groups in process: An introduction to small group communication, 6th ed. Boston: Allyn and Bacon.

Bates, A.W. \& Poole, G. (2003). Effective teaching with technology in higher education. San Francisco: Jossey-Bass.

Beebe, S. \& Masterton, J. (2006). Communicating in small groups: Principles and practices, 8th ed. Boston: Pearson.

Bergeron, K. \& Melrose, S. (2006). Online graduate health care learners' perceptions of group work and helpful instructional behaviors. Journal of Educational Technology, 3(1), 74-80.

Carr, D., Herman, E., Zarotney-Keldsen, S., Miller, J. \& Wakefield, P. (2005a). The team learning assistant workbook. Boston, MA, USA: McGraw-Hill Irwin.

Carr, D., Herman, E., Zarotney-Keldsen, S., Miller, J \& Wakefield, P. (2005b). The quick start guide $\mathcal{E}$ instructor's resource manual to accompany the team learning assistant workbook. Boston, MA, USA: McGraw-Hill Irwin.

Christophel, D. M. (1990). The relationship among teacher immediacy behaviors, student motivation, and learning. Communication Education, 39(4), 323-340.

Christophel, D. M., \& Gorham, J. (1995). A test-retest analysis of student motivation, teacher immediacy, and perceived sources of motivation and demotivation in college classes. Communication Education, 44, 292-306.

Clark, C. C. (2003). Group leadership skills, 4th ed. New York: Springer. 
Collison. G., Elbaum, B., Haavind, S. \& Tinker, R. (2000). Facilitating online learning effective strategies for moderators. Atwood Publishers, Madison, WI.

Creese, E. (2003, November). Group dynamics and learning in an organization behaviour virtual learning community: The case of six virtual peer-learning teams. UltiBASE. http:/ / ultibase.rmit.edu.au/Articles/ nov03/creese2.htm [viewed 24 Feb 2007].

Denzin, N.K., \& Lincoln, Y.S. (1994). Handbook of qualitative research. Thousand Oaks, CA: Sage.

Eggleston, T., \& Smith, G. (2002). Parting ways: ending your course. Association for Psychological Science Observer, 15(3). [viewed 24 Feb 2007] http: / / www.psychologicalscience.org/teaching/tips/tips_0302.cfm

Gabriel, M.A. (2004). Learning together: Exploring group interactions online. Journal of Distance Education, 19(1), 54-72.

Garrison, D. R., Anderson, T. \& Archer, W. (2000). Critical thinking in text-based environment: Computer conferencing in higher education. The Internet and Higher Education, 2(2), 87-105.

Giddings, L. S., Campbell, S. \& Maclaren, P. (2006). Going online to learn health sciences research methods: The student experience. Australasian Journal of Educational Technology, 22(2), 251-267. [viewed 24 February 2007] http: / / www.ascilite.org.au/ajet/ajet22/giddings.html

Gorham, J. (1988). The relationship between verbal teacher immediacy behaviors and student learning. Communication Education, 37(1), 40-53.

Hess, J.A. \& Smythe, M.J. (2001, Fall). Is teacher immediacy actually related to student cognitive learning? Communication Studies. [viewed 24 Feb 2007] http: / / www.findarticles.com/p/articles / mi_qa3669/is_200110/ai_n8997667

Hutchins, H.M. (2003). Instructional immediacy and the seven principles: Strategies for facilitating online courses. Online Journal of Distance Learning Administration, 6(3). [viewed $24 \mathrm{Feb} 2007$ ] http: / / www.westga.edu/ distance/ ojdla/ fall63/ hutchins63.html

Johnson, D. W. \& Johnson F. P. (1997). Joining together: Group theory and group skills. Boston: Allyn \& Bacon.

Johnson, D. W. \& Johnson, F. P. (2000). Joining together (7th Ed.) Boston: Allyn \& Bacon.

Kelly, G. A. (1955). The psychology of personal constructs (2 vols). New York: Norton.

Lincoln, Y.S. \& Guba, E.G. (1985). Naturalistic inquiry. Thousand Oaks, CA: Sage.

Loiselle, C., Profetto-McGrath, J., Polit, D. \& Beck, C. (2007). Canadian essentials of nursing research. 2nd ed. Toronto, ON, Canada: Lippincott.

Maslow, A. (1982). Toward a psychology of being, 2nd ed. Princeton, NJ, USA: Van Nostrand. 
Mehrabian, A. (1967). Attitudes inferred from nonimmediacy of verbal communication. Journal of Verbal Learning and Verbal Behavior, 6, 294-295.

Mehrabian, A. (1971). Silent messages. Belmont, CA: Wadsworth Publishing Co.

Melrose, S., Shapiro, B., \& LaVallie, C., 2005. Help-seeking experiences of health care learners in a WebCT online graduate study program. Canadian Journal of Learning and Technology 31(2), 5-21. [viewed 24 Feb 2007] http: / / www.cjlt.ca/ content/vol31.2/ melrose.html

Melrose, S., (2006). Facilitating help-seeking through student interactions in a WebCT online graduate study program. Nursing and Health Sciences, 8, 175-178.

Melrose, S. \& Bergeron, K. (2006) Online graduate study of health care learners' perception of instructional immediacy. International Review of Research in Open and Distance Learning 7 (1). [viewed 24 Feb 2007] http: / / www.irrodl.org/index.php/irrodl/article/view/255/ 497

McLouglin, C. (2002). Computer supported teamwork: An integrative approach to evaluating cooperative learning in an online environment. Australian Journal of Technology, 18(2), 227-254. [viewed 24 Feb 2007] http:/ / www.ascilite.org.au/ajet/ajet18/mcloughlin.html

Palloff, R. \& Pratt, K. (1999). Building learning communities in cyberspace: Effective strategies for the online classroom, San Francisco: Jossey-Bass.

Piaget, J. (1954). The construction of reality in the child. New York: Basic Books.

Russo, T., \& Benson, S. (2005). Learning with invisible others: Perceptions of online presence and their relationship to cognitive and affective learning. Educational Technology E Society, 8(1), 54-62. http:/ / www.ifets.info/journals/8_1/8.pdf [viewed $24 \mathrm{Feb} 2007$ ].

Salmon, G. (2004). E-moderating: the key to teaching E learning online.2nd edition. Oxon, UK: Talyor \& Francis Books Ltd.

Schutz, W. (1958). The interpersonal underworld. Palo Alto, CA, USA: Science and Behavior Books.

Stacey, E. \& Rice, M. (2002). Evaluating an online environment. Australian Journal of Education Technology, 18(3), 323-340. http:/ / www.ascilite.org.au/ajet/ajet18/ stacey.html

Tuckman, B. (1965). Developmental sequence in small groups. Psychological Bulletin, 63(6), 384-399.

Tuckman, B. \& Jensen, M. (1977). Stages of small group development. Group and Organizational Studies, 2(4), 419-427.

Vygotsky, L. (1978). Mind in society: The development of higher psychological processes. Cambridge, MA: Harvard University Press.

Westberg, J. \& Jason, H. (1996). Fostering Learning in Small Groups: A Practical Guide. New York: Springer. 
Wiener, M. \& Mehrabian, A. (1968). Language within language: Immediacy, a channel in verbal communication. New York: Appleton-Century-Crofts.

Woods, R.H. \& Baker, J.D. (2004). Interaction and immediacy in online learning. International Review of Research in Open and Distance Learning, 5(2).

http: / / www.irrodl.org/index.php/irrodl/article/viewArticle/186/268 [viewed 24 Feb 2007].

Yonge, O., Lee, H. \& Luhanga, F. (2006). Closing and not just ending a course. Nurse Educator, 31(4), 151-152.

Sherri Melrose $P h D, R N$, Assistant Professor

Kim Bergeron MHST, Research Assistant

Centre for Nursing and Health Studies, Athabasca University

1 University Drive, Athabasca, Alberta, Canada, T9S 3A3

Email: sherrim@athabascau.ca

Sherri Melrose facilitates university student learning groups, community educational support groups and in-patient psychiatric therapy groups. Ms Bergeron completed graduate studies in the MHST program at Athabasca University and facilitates training sessions for health care professionals, community stakeholders and non-profit organisations. 